\title{
Determinants of Individual Taxpayers' Compliance in Indonesia: A Meta-Analysis
}

\author{
OKTA HANDAYANI \\ THERESIA WORO DAMAYANTI* \\ Universitas Kristen Satya Wacana
}

\begin{abstract}
This research presents a meta-analysis towards 31 studies regarding the tax compliance in Indonesia from 2010-2015. This study examined the influence of the tax's service quality, tax knowledge, taxpayer awareness, tax socialization, tax sanctions and attitudes of taxpayers to the taxpayer compliance in Indonesia. The purpose of this study is to strengthen the findings of previous research that the dependent variable is affecting taxpayer compliance in Indonesia. Used meta-analysis, this study obtained empirical evidence that all the dependent variables are the quality of tax services, tax knowledge, taxpayer awareness, tax socialization, tax sanctions and attitudes of taxpayers positively affects the taxpayer compliance of individuals in Indonesia.
\end{abstract}

Keywords: Taxpayers Compliance, Meta-Analysis, Tax's Service Quality, Tax Knowledge

Intisari: Penelitian ini menyajikan meta-analisis terhadap 31 penelitian mengenai kepatuhan pajak di Indonesia dari tahun 2010-2017. Studi ini menguji pengaruh kualitas pelayanan pajak, pengetahuan pajak, kesadaran wajib pajak, sosialisasi pajak, sanksi pajak dan sikap pembayar pajak untuk kepatuhan wajib pajak di Indonesia. Tujuan penelitian ini adalah untuk memperkuat temuan penelitian sebelumnya bahwa variabel dependen mempengaruhi kepatuhan wajib pajak di Indonesia. Dengan menggunakan meta-analisis, penelitian ini memperoleh bukti empiris bahwa semua variabel dependen adalah kualitas jasa perpajakan, pengetahuan pajak, kesadaran wajib pajak, sosialisasi pajak, sanksi pajak dan sikap wajib pajak berpengaruh positif terhadap kepatuhan wajib pajak individu di Indonesia.

Kata Kunci: Kepatuhan Wajib Pajak, Meta-Analisis, Kualitas Pelayanan Pajak, Pengetahuan Pajak

\footnotetext{
* Corresponding author: woro@staff.uksw.edu
} 


\section{Introduction}

The tax currently contributes to more than $70 \%$ of total government's income, making tax the most significant source of income for the government. However, data show a low level of tax compliance, especially of individual taxpayers. Pandiangan (2011) reveals that the taxpayers' compliance in Indonesia was only 58.165 in Indonesia. This figure is even significantly higher than the 2008 figure that was only $33.08 \%$ and the 2009 figure that reached 54.15\%. Manurung (2013) demonstrates that in 2012, individual taxpayers who pay their tax obligation and submit their tax returns and constitute only $44 \%$ of total registered individual taxpayers.

Another indicator of tax compliance in Indonesia is tax ratio. In 2014, Indonesia's tax ratio was only $12.2 \%$, lower than other countries, such as the Philippines (16.7\%), Malaysia (15.9\%), Singapore (13.9\%), South Africa (27.8\%), Cameroon (16.1\%) and much lower than OECD countries (34.2\%). In 2015, the tax compliance of individual taxpayers was still low (58\%) and still dominated by employees. During the last ten years, the tax target has never been achieved. Even, according to the Center for Indonesian Taxation Analysis or CITA (2017), the tax revenue realization in 2015 (81.5\%) and 2016 (83\%) were the lowest ones. Even Sri Mulyani, the Indonesian Minister of Finance, acknowledged that the tax ratio in 2016 was meager (11\%) (Warta Ekonomi 2017). The government has responded to this phenomenon by increasing the tax income target to finance the national development and the existence of the nation.

It is not easy to increase the targeted government income from tax because the government and its apparatus have to deal with various obstacles. One of the most significant obstacles is that taxpayers still exhibit low compliance and many taxpayers do not submit their tax returns and do not pay their taxes. Taxpayers' compliance is crucial for the government because low tax compliance implies decreased tax income that eventually will impede national development. Indonesia adopts 3 (three) taxation system, including self-assessment system in which taxpayers are authorized to determine, calculate, pay and report their taxes to tax official (Mardiasmo 2011:7). In 
other words, taxpayers have full responsibility to act effectively, compliantly and honestly in tax payment.

According to Jotopurnomo and Mangoting (2013), there are internal and external factors that affect taxpayers' compliance to pay tax. The internal factors are from taxpayers themselves and are closely related to the individual characteristics that lead them to commit their tax obligation. The internal factors include educational level, tax consciousness, level of understanding of tax regulations and rational factor. The external factors refer to taxpayers" environment and situation.

In Indonesia, numerous studies have analyzed factors that affect taxpayers' compliance in performing their tax obligation. Rahmawati and Rasmini (2012) emphasize that tax service quality, taxpayers' awareness, tax socialization and tax sanction positively affect taxpayers' compliance. However, Winerungan (2013) reveals that tax officials' service quality, tax socialization, and tax sanction do not significantly affect taxpayers' compliance. Syahril (2013) find that tax service quality and tax knowledge affect individual taxpayers' compliance in Indonesia. Also focusing on individual taxpayers, Tiraada (2013) indicates that taxpayers' awareness, tax sanction, and taxpayers' attitude. Muliari and Setiawan (2011) demonstrate that tax sanction and taxpayers' awareness influence individual taxpayers' compliance. Andinata (2015) show that taxpayers' awareness and the effectiveness of taxation system influence individual taxpayers' compliance in Indonesia. However, the quality of tax service and tax sanction do not exhibit significant effects on taxpayers' compliance. Mahardika (2015), Muarifah (2014), Halim and Ratnawati (2014), and Rosyada (2015) find that tax service quality and taxpayers' attitude exhibit significant influences on individual taxpayers' compliance. According to Utami and Kardinal (2013), tax sanction affects taxpayers' compliance while taxpayers' awareness does not exhibit a significant influence on individual taxpayers' compliance. Susanto (2013) demonstrates that tax service quality, tax knowledge and perception on corruption do not influence individual taxpayers' compliance. There are still many other studies investigating factors that affect individual taxpayers' compliance. 
Previous studies exhibit different and even conflicting results, making it difficult to make a substantive conclusion. Therefore, it is necessary to synthesize and analyze previous relevant empirical studies to generalize and to test the validity of a substantial body of research on a particular topic. In the taxpayers' compliance issue, it is important to synthesize and analyze previous relevant studies that investigate taxpayers' compliance because they are conducted in different time periods and possibly in different legal context. These studies also use different research designs, such as different variables or different approaches to measuring variables. Conflicting results of previous studies potentially limit the theoretical development and the research implementation (Garcia-Meca dan Sanchez-Ballesta, 2009).

One can rely on the meta-analysis approach to analyze several primary research quantitatively. According to Cooper (1982), a meta-analysis is a statistical tool that combines data from previous similar studies to generate a summary. Meta-analysis aims to integrate existing research. In this context, this study analyzes previous primary studies that investigate factors that affect individual taxpayers' compliance in fulfilling their tax obligation, especially in Indonesia. Previous literature in this issue exhibits different results, making it difficult to make an accurate conclusion about factors that affect individual taxpayers' compliance in fulfilling their tax obligation. It is then expected that meta-analysis of these studies generates a conclusion on the variety of the results.

\section{Theoretical Framework and Hypothesis Development}

\subsection{Meta-Analysis of Tax Compliance in Indonesia}

A meta-analysis is a research approach that aims to overcome problems commonly found in quantitative social studies, including taxation. Numerous studies on the same topic are likely to exhibit different, and even conflicting, results for the same variables. This inconsistency complicates readers to make a general conclusion. According to Widhiastuti (2002), a meta-analysis combines, improves and creates a foundation for theory development and decision making, including in policymaking. Meta-analysis is also useful to summarize, integrate and interpret previous studies 
statistically of a particular subject statistically. In other words, meta-analysis is an analysis of numerous analyses that have been conducted before (Fanani, 2014). In a meta-analysis study, one has to determine relevant studies to select their hypotheses. In this study, we analyze several relevant variables such as individual taxpayers' compliance, the quality of tax service, tax knowledge, taxpayers' awareness, tax socialization, tax sanction and taxpayers' attitude to investigating how many previous studies use these variables.

Nineteen studies analyze the effect of the quality of tax service on individual taxpayers' compliance. Three of them (Winerungan, 2013; Andinata, 2015; Susanto, 2013) find that there is the quality of tax service does not affect individual taxpayers' compliance. Nine studies investigate the effect of tax knowledge on individual taxpayers' compliance, and one of them shows that there is no effect of tax knowledge on individual taxpayers' compliance. Ten and five papers examine the effects of taxpayers' awareness and attitude on taxpayers' compliance, respectively. These studies consistently demonstrate that taxpayers' awareness and attitude is positively correlated with individual taxpayers' compliance. Sixteen studies analyze the role of tax sanction in explaining taxpayers' compliance, with 14 of them show a positive correlation and two studies find no significant effect of tax sanction on individual taxpayers' compliance. Seven studies investigate the effect of tax socialization on taxpayers' compliance, and only two of them (one of them is Winerungan [2013]) indicate that tax socialization does not influence individual taxpayers' compliance. In selecting independent variables in this study, we require that these variables have to be analyzed in at least three previous studies. This criterion generates the following variables to test our hypotheses: tax compliance, tax service quality, tax knowledge, tax awareness, tax socialization, tax sanction and taxpayers' attitude.

\subsection{The Effect of Tax Service Quality on Individual Taxpayers' Compliance}

According to Tjiptono (2001), quality is a dynamic condition that is closely related to products, services, human resources, processes and environment that meets or exceeds expectation. Service is a process to assist others by using a certain way that 
requires sensitivity and interpersonal relation to generate satisfaction and success (Budiono, 2003:60). Tax officials are officials from tax offices that specially administer the Indonesian tax. According to Devano et al. (2006:112), the quality of tax service is related to all activities conducted in tax offices as a means to fulfill taxpayers' needs as stipulated by the regulations that eventually aims to increase taxpayers' satisfaction and to increase taxpayers' compliance.

Tax service quality can be measured by the ability of tax officials to provide satisfactory services, to offer a proper response, and to be polite and trustworthy. Sufficient physical facilities, including communication devices, are also necessary for providing a reliable service. When tax officials exhibit these features, taxpayers are likely to feel comfortable in fulfilling their tax obligation and eventually taxpayers' compliance will increase. In other words, better tax service implies higher taxpayers' compliance and worse tax service discourages taxpayers to fulfill their tax obligation. Syahril (2013), Rohmawati and Rasmini (2012), Jotopurnomo and Mangoting (2013), Jatmiko (2006), Andyastuti et al. (2013) and Susanto (2013) argue that the quality of tax officials' service positively affects taxpayers' compliance. Based on the previous arguments, we propose the following hypothesis:

H1. Tax service quality positively affects individual taxpayers' compliance.

\subsection{The Effect of Tax Knowledge on Individual Taxpayers' Compliance}

Notoatmodjo (2007) defines knowledge as a result of the knowing process after one senses a certain object. The sensing process generates the senses of sight, hearing and thinking as the basis of one's action and behavior. Tax knowledge consists of filling in tax return correctly, determining tax according to existing tax regulations, timely tax payment and so on. If taxpayers possess sufficient tax knowledge, then it is likely that they will perform all their tax obligation as stipulated by existing tax regulations. Eventually, taxpayers' compliance in fulfilling their tax obligation will increase. For example, if taxpayers do not fully understand how to calculate their tax when to submit their tax return and so on, they will lack understanding on how to fulfill their tax obligation. Muslim (2007:11) emphasizes that when taxpayers exhibit a 
greater understanding of tax regulations, it is less likely that they will violate these tax regulations, leading to higher taxpayers' compliance. Widyastuti (2015), Ratno et al. (2014), Muarifah (2014), Syahril (2013), (2015) suggest that tax knowledge significantly affects taxpayers' compliance. Based on the previous arguments, the following is our second hypothesis:

H2. Tax knowledge positively affects individual taxpayers' compliance.

\subsection{The Effect of Taxpayers' Awareness on Individual Taxpayers' Compliance}

Taxpayers' awareness is a condition when taxpayers understand, acknowledge and comply with existing tax regulation and are consciously willing and able to fulfill their tax obligation. Suyatmin (2004) proposes that taxpayers' positive assessment of governments' state functions encourages citizens to fulfill their tax obligation. Positive assessment implies that taxpayers are aware of the function of tax in supporting the development and refusing to pay taxes will only hinder national development. Taxpayers with positive assessment will consciously exhibit greater compliance in fulfilling their tax obligation because they perceive that not fulfilling tax obligation will bring about disadvantages to their countries and inhibit national development. According to Andinata (2015), awareness influences taxpayers' compliance. Similarly, Jotopurnomo and Mangoting (2013), Rohmawati and Rosmini (2012), and Jatmiko (2006) indicate that awareness has a positive effect on compliance. Furthermore, we propose the following hypothesis:

H3: Awareness positively affects individual taxpayers' compliance

\subsection{The Effect of Tax Socialization on Individual Taxpayers' Compliance}

According to Kotler (2005), service refers to any activities offered by a party to another party that is intangible and does not imply any ownership. Pudji (2007) observes that socialization is a form of education that adjusts its method, materials, and means with targets' condition, needs, and means. It can be concluded that socialization is a form of non-formal education. Tax socialization is an effort of tax offices to inform, to increase public understanding and educate the public about tax regulations. Tax socialization aims to increase taxpayers' level of understanding about 
tax, their awareness of the importance of paying and reporting their taxes. Aini (2013), Andyastuti et al. (2013), Pamuji et al. (2014), and Rohmawati and Rosmini (2012) mention that socialization positively affects taxpayers' compliance. Furthermore, we propose the following hypothesis:

\section{H4. Tax socialization positively affects individual taxpayers' compliance}

\subsection{The Effect of Tax Sanction on Individual Taxpayers' Compliance}

The sanction is a negative punishment to someone who violates a certain regulation. Tax sanction is a means to deter taxpayers from violating tax norms (Mardiasmo,2006:39). In general, acts and regulations contain rights and obligations, and permitted actions. Acts and regulations must contain sanctions to those who violate to encourage the public to comply with these acts and regulations. Tax laws are no exception. Tax sanctions aim to deter taxpayers from neglecting their tax obligations. In the Indonesian tax system, there are two forms of tax sanctions, namely administrative and criminal sanctions. Nugroho et al. (2006) argue that taxpayers will fulfill their tax obligation if they perceive that tax sanctions will be much cost to them. In other words, tax sanctions only apply to taxpayers who do not comply with tax regulations. Consequently, greater violation of tax regulations implies more tax sanctions. Rohmawati and Rosmini (2012), Putra et al. (2014), Jotopurnomo and Mangoting (2013), and Muliari and Setiawan (2011) suggest that tax sanction positively affects taxpayers' compliance in fulfilling their tax obligation. Based on the previous argument, our fifth hypothesis is:

H5. Tax sanction positively affects taxpayers' compliance.

\subsection{The Effect of Taxpayers' Attitude on Individual Taxpayers' Compliance}

Attitude plays an important role in explaining ones' behavior in their environment. Mahardika (2015) emphasizes that attitude is ones' cognitive, affective and conative product that is acquired throughout their life that can take the form of personal experience. Improved tax service quality potentially increases taxpayers' positive attitude toward tax issues that will eventually increase tax awareness. It then can be concluded that taxpayer' attitude is favorable or unfavorable taxpayer' 
evaluative consideration and statement about a certain object, person, or event (Hardika in Salman, 2008). This study defines attitude in positive and cognitive terms. Cognitive attitude consists of six aspects, ranging from knowledge to evaluation of decisions taken as the highest aspect. More positive taxpayers' attitude is likely to increase taxpayers' compliance. Mahardika (2015), Tiraada (2013), Halim and Ratnawati (2014), and Rosyada (2015) indicate that attitude positively affects taxpayers' compliance. We then propose the following hypothesis:

H6. Taxpayers' attitude positively affects individual taxpayers' compliance.

\section{Research Method}

This study is a meta-analysis that aims to combine several previous studies in individual taxpayers' compliance by using a statistical technique that generates a quantitative conclusion. More specifically, meta-analysis recapitulates facts from the existing summarized statistical procedures of previous studies, determines and measures the power of the effects of various independent variables on individual taxpayers' compliance as well as offers a theoretical interpretation based on the statistical calculation found.

This study analyzes previous studies on individual taxpayers' compliance in Indonesia for five years, namely 2010, 2011 and 2013-2015. We use the keywords of "factors affecting individual taxpayers' compliance" (in Indonesian) to generate previous studies to analyze. Additionally, these papers must be published in Indonesia, and they should have been presented at the Indonesian National Accounting Symposium (SNA - Simposium Nasional Akuntansi) because SNA is the most respectable accounting conference in Indonesia.

We narrow down further selection of previous studies to be analyzed by applying the following criteria: (1) these studies should use a quantitative approach, (2) these papers should employ independent variables that are included in at least three studies as already discussed in part one, and (3) the studies should use individual taxpayers' compliance as the dependent variable. This study consists of the following steps:

a. Selecting database and identifying of explanatory variables. 
b. Converting or statistically transforming the statistic of the size effect of each study into a single joint metric (r). For studies that do not report their (r) statistic, we transform other test-statistics into (r) by using the procedure of Lipsey and Wilson (200) and Hunter and Schmidt (1990).

c. Accumulating the size effect and calculating the average correlation coefficient (r) Following by Carcia-Meca and Sanchez-Ballesta (2009), we use the direct hypothesis testing method. This method indicates that when the average correlation is between the minimum and maximum area of the confidence interval, and all values are positive or negative, the relation is significant. If one value is negative and the other is positive, the average correlation is insignificant, and if the boundary between the minimum and maximum confidence interval is upside down, the hypothesis is not supported.

\section{Results and Discussion}

We found 31 relevant research papers that qualify our criteria. We select our independent variables if these variables are reported in at least three studies. We do not include several studies for some reasons, such as not reporting statistical values. Table 1 displays the descriptive statistics of our data. Table 1 shows that most of the papers included in this study $(68 \%)$ are from unaccredited journals. Similarly, $32 \%$ of the research papers included in this study are before the e-filling and PP 46 periods and $68 \%$ after the implementation of e-filling and PP 46.

\subsection{Hypothesis Testing}

Table 2 suggests that the quality of tax service exhibit a significantly positive effect on individual taxpayers' compliance with a correlation of 0.3126 and confidence interval of $95 \%$ between 0.261 to 0.3642 . These findings support $\mathrm{H} 1$, implying that the quality of tax service increases taxpayers' compliance

Our analysis also shows that tax knowledge affects tax compliance, supporting our $\mathrm{H} 2$. We base our conclusion on the mean value of 0.307 with the confidence interval of $95 \%$ between 0.289 and 0.325 . Similarly, taxpayers' awareness affects individual 
taxpayers' compliance because the average correlation value is 0.303 with the confidence interval of $95 \%$ between 0.289 and 0.317 . The findings imply that the higher taxpayers' awareness, the higher their compliance to pay tax, empirically supporting H3.

Related to $\mathrm{H} 4$, our analysis reveals similar results. With the mean value of the correlation of 0.2927 and the confidence interval of $95 \%$ between 0.2676 and 0.3179 . These findings support $\mathrm{H} 4$, suggesting a positive and robust effect of tax socialization on individual taxpayers' compliance. Besides, our results support H3 (mean of 0.289 with a confidence interval of $95 \%$ between 0.2519 and 0.321 ). These findings indicate a positive and strong effect of tax sanction on individual taxpayers' compliance. Lastly, H6 is also empirically supported, suggesting that taxpayers' attitude positively affects individual taxpayers' compliance. More specifically, our analysis to test H6 reveals that the average correlation is 0.414 with the confidence interval of $95 \%$ between 0.379 and 0.4500 .

Table 1

Research Data

\begin{tabular}{lll}
\hline & $\mathbf{N}$ & $\mathbf{\%}$ \\
Journals Accreditation & & \\
$\quad$ Accredited & 10 & $32 \%$ \\
$\quad$ Unaccredited & 21 & $68 \%$ \\
\hline $\begin{array}{l}\text { Before vs. after the implementation of e-filing } \\
\quad<2013\end{array}$ & 10 & $32 \%$ \\
$\quad>2013$ & 21 & $68 \%$ \\
\hline Before vs. after the implementation of PP 46 & & \\
$\quad<2013$ & 10 & $32 \%$ \\
$\quad>2013$ & 21 & $68 \%$ \\
\hline Period of Tax Socialization & & \\
$\quad<2015$ & 31 & $100 \%$ \\
$\quad>2015$ & 0 & 0 \\
\hline
\end{tabular}


Table 2

Meta-Analysis

\begin{tabular}{|c|c|c|c|c|c|c|c|c|}
\hline $\begin{array}{l}\text { Explanatory } \\
\text { Variable }\end{array}$ & $\mathbf{n}$ & study & $\mathbf{r}$ & S2r & S2e & S2p & $\begin{array}{l}\text { 95\% Convidence } \\
\text { Interval }\end{array}$ & $X^{\wedge} 2 \mathrm{k}-1$ \\
\hline $\begin{array}{l}\text { Quality of } \\
\text { tax service }\end{array}$ & 1749 & 19 & 0,3126 & 0,0349 & 0,0086 & 0,0263 & $0,261-0,3642$ & 77,0721 \\
\hline $\begin{array}{l}\text { Tax } \\
\text { knowledge }\end{array}$ & 1136 & 9 & 0,307 & 0,015 & 0,006 & 0,009 & $0,289-0,325$ & 21.519 \\
\hline $\begin{array}{l}\text { Taxpayers' } \\
\text { awareness }\end{array}$ & 865 & 10 & 0,303 & 0,016 & 0,009 & 0,006 & $0,289-0,317$ & 17.313 \\
\hline Socialization & 960 & 7 & 0,2927 & 0,0189 & 0,0060 & 0,0128 & $0,2676-0,3179$ & 21,73 \\
\hline Sanction & 1486 & 16 & 0,2869 & 0,0267 & 0,0090 & 0,0177 & $0,2519-0,321$ & 47,265 \\
\hline $\begin{array}{l}\text { Taxpayers } \\
\text { attitude }\end{array}$ & 400 & 4 & 0,414 & 0,02 & 0,006 & 0,017 & $0,379-0,4500$ & 14,501 \\
\hline
\end{tabular}

Our study also indicates that the effect of tax service on our dependent variable before the implementation of e-filling differs from the post-implementation period. More specifically, before e-filling, the effect exhibits r-value of 0.277 with the confidence interval of $95 \%$ between 0.258 and 0.295 . After the implementation of efilling, the effect increases as the $r$ value is 0.333 with the confidence interval of $95 \%$ is between 0.264 and 0.4 .

The effect of tax knowledge on taxpayers' compliance for papers from the accredited journals also differs from the same effect for papers in the unaccredited journal. For papers from the unaccredited journals, the correlation is negative with $\mathrm{r}$ of 0.3325 , and the confidence interval of $95 \%$ is between 0.350 and 0.314 . For papers from the accredited journals, the correlation is positive with $\mathrm{r}$ of 0.277 and the confidence interval of $95 \%$ between 0.234 and 0.321 . 
We classify our paper sample into the pre- and post- PP 46 period in 2013 to represent the tax socialization. Our findings show that for both periods the positive effect of tax socialization on Indonesian individual taxpayers' compliance. However, the post-PP 46 period exhibits an increasing effect. More specifically, the pre-PP 46 exhibits the r-value of 0.243 with the confidence interval of $95 \%$ between 0.252 and 0.234. After the implementation of PP 46, the $r$ value increases to 0.31 with the confidence interval of $95 \%$ between 0.273 and 0.346 . These findings suggest a greater intensity of tax socialization increases individual taxpayers' compliance.

Table 3

Meta -Analysis- Moderating Variable

\begin{tabular}{|c|c|c|c|c|c|}
\hline \multirow{2}{*}{$\begin{array}{l}\text { Explanatory } \\
\text { Variable }\end{array}$} & \multirow[b]{2}{*}{ Moderating Variable } & \multicolumn{2}{|c|}{ Before Moderating } & \multicolumn{2}{|c|}{ After Moderating } \\
\hline & & $\mathbf{r}$ & $\begin{array}{l}95 \% \\
\text { Confidence } \\
\text { Interval }\end{array}$ & $\mathbf{r}$ & $\begin{array}{l}95 \% \\
\text { Confidence } \\
\text { Interval }\end{array}$ \\
\hline $\begin{array}{l}\text { Quality of tax } \\
\text { service }\end{array}$ & $e$-filing period & 0.277 & $0.258-0.295$ & 0.333 & $0.264-0.400$ \\
\hline Tax Knowledge & Accredited Journal & 0.332 & $0.350-0.314$ & 0.277 & $0.234-0.321$ \\
\hline Socialization & PP 46 period & 0.243 & $0.252-0.234$ & 0.311 & $0.2730-0.346$ \\
\hline
\end{tabular}

\subsection{Discussion}

This study shows that tax service quality affects tax compliance in Indonesia. The government began to reform the tax system in 1984. Since then, Indonesia has applied the self-assessment system that gives taxpayers authority to determine their tax (Mardiasmo, 2009). Consequently, the Directorate General of Taxes has to perform the activities of tax service, supervision, consultation, and sanction. Better tax officials' service quality is likely to increase taxpayers' compliance in fulfilling their tax obligation. High-quality services should continuously offer security, comfort, ease as well as the legal certainty to customers so that customers are satisfied with these services. Service quality can be measured with satisfactory, responsive, polite, communicative services and trustworthy tax officials. Good communication enables 
tax officials to understand taxpayers' needs better. Furthermore, the availability of sufficient facilities also increases tax service quality. Based on these arguments, it can be concluded that better tax service quality likely increases taxpayers' compliance in fulfilling their tax obligation. In this recent period, service quality is not only related to the quality of human resources or facilities but also the availability of advanced technology that enables taxpayers to fulfill their tax obligation.

Nowadays, people rely on the internet for their daily activities at an increasing rate and tax is not an exception. The Internet enables the Directorate General of Taxes to modernize their tax system to increase their service quality. More specifically, tax system modernization allows taxpayers to fulfill their tax obligation without having to go to their respective regional tax offices. Since 2013, individual taxpayers can submit their income tax returns through e-filling. This internet-based system enables individual taxpayers to submit their annual income tax returns quickly and practically, and they do not have to go to regional tax offices.

In both pre- and post- tax system modernization periods, tax service quality affects tax compliance. However, tax compliance increases after modernization because the tax system modernization enables taxpayers, especially individual ones, to fulfill their tax obligation. This study also finds that tax knowledge likely increases tax compliance. Tax knowledge consists of various components, such as filling in tax returns correctly, tax calculation based on existing tax regulations, timely tax payment and so on. If taxpayers do not know how to determine their taxes or when to submit their annual tax returns, they may have difficulties in fulfilling their tax obligation. However, when taxpayers have sufficient knowledge about these tax issues, it is likely that they fulfill their tax obligation correctly and their compliance increases.

We also partition our analysis based on the accreditation status of journals where papers are published. The results demonstrate that for papers from unaccredited journals, tax knowledge does not affect individual taxpayers' compliance in Indonesia, as indicated by the r-value of 0.3321 with the confidence interval of $95 \%$ between 0.3455 and 0.3188 (see Table 3). The findings exhibit standard error that is too high, indicating that tax knowledge does not influence taxpayers' compliance. Our results 
are similar to Susanto (2013) who shows that tax knowledge is less likely to affect behavior because knowledgeable taxpayers may still be reluctant to fulfill their tax obligation. Various factors may explain this phenomenon, such as taxpayers' environment is not tax-compliant and lack of patriotism because some taxpayers may perceive that paying tax is less useful because they will not receive direct compensation from the government.

Taxpayers' awareness also positively affects tax compliance. It is necessary for each taxpayer to be aware of the role of tax in supporting the national development. Not paying taxes according to the existing regulations will only cause a financial loss to the state. Ones who have a positive assessment on the role of tax will consciously exhibit greater compliance in fulfilling their tax obligation because they perceive that refusing to pay tax will cause a financial loss to governments and hinder national development. Higher awareness of tax importance in supporting national development increases taxpayers' compliance. A greater tax awareness also motivates taxpayers to fulfill their tax obligation. Eventually, tax knowledge also increases taxpayers' awareness because formal or informal tax knowledge positively affects taxpayers' awareness to fulfill their tax obligation (Palil, 2005).

This research also finds that tax socialization likely affects individual taxpayers' compliance. Tax socialization is a form of non-formal education. The Directorate General of Taxes through their tax offices intensifies tax dissemination to provide tax information and education about all matters related to tax regulation and to increase public understanding of tax. Tax socialization or dissemination likely increases taxpayers' understanding and knowledge and their awareness of the importance of paying and reporting their taxes. More frequent tax socialization by tax officials also increases the number of taxpayers who have sufficient tax knowledge and eventually their tax compliance.

In 2013, the Indonesian government issued Government Regulation ( $P P$ Peraturan Pemerintah) PP 46 that regulates income tax on taxpayers' business activities with a certain gross turnover. PP 46 stipulates that individual or corporate taxpayers that generate a gross annual turnover of up to $\mathrm{Rp} 4,800,000,000$ be subject 
to a final tax of $1 \%$ from the gross turnover. This regulation aims to (1) simplify existing regulations and make it easier for taxpayers to calculate and report their taxes (2) increase taxpayers' understanding that tax is simple, especially they can calculate their taxes by multiplying their gross turnover with $1 \%$, (3) increase taxpayers' transparency in fulfilling their tax obligation, and (4) to give more opportunities to public, or more specifically taxpayers, to contribute to the national development.

Public, especially taxpayers, should understand that the implementation of this new government regulation requires intensive socialization from the government, especially the Directorate General of Taxes. Tax socialization educates taxpayers on the change in government regulation, through both electronic and printed media. Because PP 46 aims to facilitate taxpayers, the tax socialization on this new regulation will likely attract the public to fulfill their tax obligation. In both the pre- and post- PP 46 implementation periods, tax socialization positively affects individual taxpayers' compliance. However, after the implementation of PP 46, taxpayers' compliance increases (see Table 4). The findings indicate that intensive socialization on the change of the government regulation increases taxpayers' compliance, especially individual ones. The socialization not only educates the public but also guides them to consciously start paying the tax due to the importance of tax to sustain the country.

This study demonstrates that tax sanction affects individual taxpayers' compliance. Tax sanction encourages taxpayers to be aware of and to comply with tax obligations. Existing tax regulations mention two forms of sanction: administrative (fine and interest) and criminal sanctions. It is expected that tax sanction increases taxpayers' compliance. Act No. 28 year 2007 Article 7 (1) stipulates that if tax return is not submitted during the period as mentioned in Article 3 clause (3) or during the extended period of tax return submission as mentioned in Article 3 clause (4), taxpayers will be charged the following fine sanctions of Rp500,000.00 (five hundred thousand rupiah) for Periodic Value Added Tax Return, Rp100,000.00 (a hundred thousand rupiah) for other periodic tax return, Rp 1,000,000.00 (a million rupiah) for Annual Corporate Income Tax Return, and Rp100,000.00 (a hundred thousand rupiah) for Annual Individual Income Tax Return. Interest as an administrative sanction will 
be charged to taxpayers who have paid their tax obligation but not yet paid correctly. In this context, taxpayers themselves prepare tax correction before tax inspection. If the correction causes tax liability, taxpayers will be charged the interest of $2 \%$ per month of that is computed by calculating the time difference between tax payment and interest payment with the maximum period of payment of tax underpayment and its interest is 24 months. After 2007, the percentage of administrative sanction increased from $12.24 \%$ to $13.30 \%$. From 2003 to 2014, tax income increased from Rp 280.6 trillion to $\mathrm{Rp} 856.572$ trillion. Income tax, value-added tax and sales tax on luxury goods are the main contributors of tax income (www.kemenkeu.go.id). These figures demonstrate that compliant taxpayers will increase tax revenue and, more importantly, tax sanction significantly affects individual taxpayers' compliance.

Attitude significantly explain ones' behavior in their environment. Taxpayers' attitude is the product of their experience. This study also shows that taxpayers' attitude likely influences their tax compliance. More specifically, positive and cognitive attitudes affect taxpayers' compliance. The government can increase taxpayers' positive attitude by increasing their tax service quality that potentially increases taxpayers' understanding of tax and their awareness on the importance of fulfilling tax obligation. Eventually, taxpayers who exhibit a positive attitude will increase their tax compliance.

President Joko Widodo set 2015 as the year of nurturing taxpayers. The government intensified tax socialization and education to encourage registered taxpayers who do not report their tax returns or who do not report their tax returns correctly to improve their tax compliance. As a country that adopts the self-assessment system (taxpayers have the authority to determine their tax liability based on existing tax regulations), taxpayers' attitude plays a very significant role in explaining tax compliance. Tax socialization and education will increase taxpayers' knowledge and positive attitude that will eventually increase their tax compliance. Taxpayers who have a positive attitude and awareness on the importance of tax in a country will motivate themselves to fulfill their tax obligation. 


\section{Conclusion, Limitation, and Suggestion}

\subsection{Conclusion dan Limitation}

Our paper is a meta-analysis study that analyzes individual taxpayers' compliance in Indonesia. Our results show that tax service quality, tax knowledge, taxpayers' awareness, tax socialization, tax sanction and taxpayers' attitude affect taxpayers' compliance.

This study is a subject to the following caveats. First, it is likely that the papers examined exhibit different research quality because some papers appear in accredited journals while others in unaccredited journals. Second, we focus on studies published in 2013-2015, thus limiting the generalization of this study. Finally, we use publication year as the indicator of pre- and post- (e-filling and PP 46) periods. However, it is more appropriate to use year in which research activities are conducted as the indicator because publication years do not necessarily reflect years in which data are collected.

\subsection{Suggestion}

Public expect the government to increase their tax service. However, it is more critical to educate taxpayers about the importance of tax for a state. Knowledgeable taxpayers are likely aware of the importance of tax. Tax knowledge consists of all matters related to the rights and obligation of taxpayers, starting from having taxpayer identification number (NPWP -Nomor Pokok Wajib Pajak), paying tax, the time boundary of tax reporting, tax sanction, and their tax rights. Taxpayers can increase their tax knowledge not only from formal education but also from the informal one. The government can increase taxpayers' knowledge through tax socialization. Tax socialization can use various media outlets, thus implying that tax officials do not have to have direct contact with taxpayers. For example, the government can use printed media, television, or even online media. Furthermore, nowadays people tend to be more practical. They perceive using online media to be more time-efficient than attending tax seminars or similar events. It is then important for tax officials to 
increase taxpayers' compliance. Several potential efforts are improving tax service quality and improving taxpayers' knowledge on tax.

\section{References}

Aini, Qurrotul.2013. "Peran Sosialisasi E-Registration Terhadap Tingkat Kepatuhan Wajib Pajak Orang Pribadi." Jurnal Akuntansi Unesa vol 2 no 1

Andinata, Monica Claudia.2015. "Analisis Faktor-Faktor yang Mempengaruhi Kepatuhan Wajib Pajak Orang Pribadi Dalam Membayar Pajak." Jurnal Ilmiah Mahasiswa Universitas Surabaya Vol.4 No.2

Andyastuti, Listiana. 2013. Pengaruh Penyuluhan, Pelayanan, Pemeriksaan, dan Sanksi Terhadap Kepatuhan Penyampaian Surat Pemberitahuan Tahunan Orang Pribadi, Jurnal Universitas Brawijaya, Malang.

Budiono, B. 2003. Pelayanan Prima Perpajakan.Jakarta: Rineka Cipta.

Cooper, H. M. 1982. Scientific guidelines for conducting integrative research reviews. Review of Educational Research, 52, 291-302.

Devano, Sony dan Rahayu. 2006. Perpajakan Konsep, Teori dan Isu. Jakarta: Kencana.Direktorat Jendral Pajak. 2016. Realisasi Penerimaan Pajak per 30 November 2015.http://www.pajak.go.id/content/article/realisasi-penerimaan-pajak-30november2015 .

Direktorat Jendral Pajak Menteri Keuangan. 2016. Www.Pajak.Go.Id. 4 23. Accessed 89 , 2016. Http://Www.Pajak.Go.Id/Content/Article/Refleksi-Tingkat-Kepatuhan-WajibPajak.

Fanani, Z. 2014. Karakteristik Perusahaan dan Corporate Governance terhadap Manajemen Laba: Studi Analisis Meta. Jurnal Keuangan dan perbankan, Vol 18, No.2 hlm. 181-200.

Fenani, Zaenal.2016. "Research Study Literature Using Meta Analysis." Teknik Analisis Data. Malang: Departemen Akuntansi Fakultas Ekonomi dan Bisnis Universitas Airlangga.

García-Meca, E., dan J. P. Sánchez-Ballesta. 2009. Corporate Governance and Earnings Management: A Meta-Analysis. Corporate Governance: An International Review, 17(5), pp. 594-610.

Halim, Donny, And Juli Ratnawati.2014. "Pengaruh Kualitas Pelayanan Dan Sikap Wajib Pajak Terhadap Kepatuhan Pelaporan Wajib Pajak." Eprints.Dinus.Ac.Id.

Hunter, J. E. dan F. L Schmidt. 1990. Methods of Meta-analysis: Correcting Error and Bias in Research Findings. Beverly Hills, CA: Sage. 
Jatmiko, Agus Nugroho. 2006. Pengaruh Sikap Wajib Pajk Pada Pelaksanaan Sanksi Denda,Pelayanan Fiskus dan Kesadaran Perpajakan Terhadap Kepatuhan Wajib Pajak.http://eprints.undip.ac.id/6812/.

Jotopurnomo, Cindy dan Yenni Mangoting. 2013. "Pengaruh Kesadaran Wajib Pajak, KualitasPelayanan Fiskus, Sanksi Perpajakan, Lingkungan Wajib Pajak Berada Terhadap KepatuhanWajib Pajak Orang Pribadi di Surabaya". Tax and Accounting Review, Vol.1, No. 1

Kotler, Philip. 2005. Manajamen Pemasaran, Jilid 1 dan 2. Jakarta: PT. Indeks Kelompok Gramedia.

L. P, Anggraini Fibria dan Waluyo. 2014. Faktor-faktor yang Mempengaruhi Kepatuhan Pajak Wajib Pajak Orang Pribadi. e-Journal Magister Akuntasi Trisakti Volume. 1 Nomor. 1 Februari 2014 Hal. 51-68.

Lipsey, M.W. dan D.B. Wilson. 2001. Practical Meta-analysis. Applied Social ResearchMethods, 49. Sage Publications, Inc. California.

Mahardika, I. G. 2015. Pengaruh Kualitas Pelayanan Dan Sikap Wajib Pajak Terhadap Kepatuhan Pelaporan Wajib Pajak Orang. Jurnal Jurusan Pendidikan Ekonomi (Jjpe) Vol 5 No 1

Mangoting, Yenni dan Arja Sadjiarto. 2013. Pengaruh Postur Motivasi Terhadap KepatuhanWajib Pajak Orang Pribadi. Jurnal Akuntansi dan Keuangan, Vol. 15, No. 2, November 2013, 106-116.

Mardiasmo. 2006, "Perpajakan, Edisi Revisi . Andi : Yogyakarta

Muarifah, Tanzilah. 2014. "Pengaruh Pengetahuan Pajak, Kualitas Pelayanan Petugas Pajak Dan Sikap Wajib Pajak Terhadap Kepatuhan Wajib Pajak (Studi Kasus Pada Wajib Pajak Orang Pribadi Yang Terdapat Pada Kpp Pratama Semarang Selatan).” Eprints.Dinus.Ac.Id

Muslim, Afdilla. 2007. Pengaruh tingkat pemahaman. Pendidikan, Pengalaman dan Penghasilan Wajib Pajak di KPP Padang. Skripsi FE Unand.

Ni Ketut Muliari \& Putu Ery Setiawan. 2011. Pengaruh Persepsi tentang Sanksi Perpajakan dan Kesadaran Wajib Pajak pada Kepatuhan Pelaporan Wajib Pajak Orang Pribadi di Kantor Pelayanan Pajak Pratama Denpasar Timur. Fakultas Ekonomi Universitas Udayana. Vol.6.1.

Notoatmodjo, S. 2007. Promosi Kesehatan dan Ilmu Perilaku. Jakarta : Rineka Cipta

Nugroho,Agus, Jatmiko. 2006. Pengaruh Sikap Wajib Pajak Pada Pelaksanaan Sanksi Denda,Pelayanan Fiskus dan 54. Tax \& Accounting Review VOL.1, NO.1 
Pamuji, Adi Ratno. 2014. Mochammad Djudi Mukzam dan Nengah Sudjana. FaktorFaktoYang Mempengaruhi Kepatuhan Pemilik Usaha Mikro, Kecil, dan Menengah (UMKM)dalam Memenuhi Kewajiban Perpajakan. Jurnal Mahasiswa Perpajakan Vol 3 No. 1.

Prastowo, Y. 2017. CITA. Retrieved May 2, 2017, from Center for Indonesia Taxation Analysis: http://www.cita.or.id/wp-content/uploads/2017/02/Siaran-Pers-CITA-OutlookPerpajakan-2017.pdf

Pudji Muljono. 2007. Learning Society, Penyuluhan dan Pembangunan Bangsa. Jurnal Penyuluhan. Vol 3(1) : Hal. 55-63.

Riko, Thomas. 2006. Analisis Tingkat PemahamanWajib Pajak Badan dan Fiskus Terhadap Perencanaan dan Penggelapan Pajak pada KPP Padang. Skripsi : FE UNAND.

Rohmawati, Alifa Nur dan Ni Ketut Rasmini. 2012. Pengaruh Kesadaran, Penyuluhan, dan Sanksi Perpajakan Pada Kepatuhan Wajib Pajak Orang Pribadi. E-Jurnal Akuntansi Universitas Unadaya. Vol. 1, No. 2.

Rosyada, Annisaa Amrina. 2015. "Pengaruh Kualitas Pelayanan Fiskus Dan Sikap Wajib Pajak Terhadap Kepatuhan Pelaporan Wajib Pajak.” Eprints.Dinus.Ac.Id.

Salman, Kautsar Riza dan Mochammad Farid. 2008. "Pengaruh Sikap dan Moral Wajib Pajak terhadap kepatuhan Wajib Pajak pada Industri Perbankan di Surabaya”. Jurnal STIE Perbanas Surabaya.

Solich Jamin (2001), Analisis Kepatuhan Wajib Pajak Sebelum dan Selama KrisisEkonomi Pada KPP di Wilayah Jawa Tengah dan DI Yogyakarta, Tesis Program Pasca Sarjana Magister Sains Akuntansi Universitas Diponegoro

Suhendri, Diyat. 2015. "Pengaruh Pengetahuan, Tarif Pajak, Dan Sanksi Pajak Terhadap Kepatuhan Wajib Pajak Orang Pribadi Yang Melakukan Kegiatan Usaha Dan Pekerjaan Bebas Di Kota Padang (Studi Empiris Pada Kantor Pelayanan Pajak Pratama Kota Padang)." Jurnal Akuntansi Ejournal.Unp.Ac.Id, 2015.

Sulistiyono, Adincha Ayuvisda. 2012. Pengaruh Motivasi Terhadap Kepatuhan Wajib PajakDalam Membayar Pajak Penghasilan Orang Pribadi Usahawan. Jurnal Akuntansi Unesa Vol.1 No 1

Supadmi, Ni Luh. 2009. Meningkatkan Kepatuhan Wajib Pajak Melalui Kualitas Pelayanan. Dalam Audi Jurnal Akuntansi Dan Bisnis. Vol 4(2), 1-14.

Susanto, Jessica Novia. 2013. Pengaruh Persepsi Pelayanan Aparat Pajak, Persepsi Pengetahuan Wajib Pajak, dan Persepsi Pengetahuan Korupsi Terhadap Kepatuhan. Jurnal Ilmiah Mahasiswa Universitas Surabaya Vol 2 No. 1

Suyatmin. (2004), Pengaruh Sikap Wajib Pajak Terhadap Kepatuhan Wajib Pajak Dalam Pembayaran Pajak Bumi dan Bangunan : Studi Empiris di Wilayah KP PBB Surakarta, Tesis Program Pasca Sarjana Magister Sains Akuntansi Universitas Diponegoro. 
Syahril, Farid. 2013. Pengaruh Tingkat Pemahaman Wajib Pajak dan Kualitas Pelayanan Fiskus Terhadap Tingkat Kepatuhan Wajib Pajak PPh Orang Pribadi.

Tiraada, Tryana A.M. 2013. Kesadaran Perpajakan, Sanksi Pajak, Sikap Fiskus TerhadapKepatuhan WPOP di Kabupaten Minahasa Selatan. Jurnal EMBA Vol.1 No.3, 999-1008.

Tjiptono, Fandy. 2001. Strategi Pemasaran. Edisi Pertama. Andi Ofset.Yogyakarta

Utami, Thia Dwi, And Kardinal. 2013. "Pengaruh Kesadaran Wajib Pajak Dan Sanksi Pajak Terhadap Kepatuhan Wajib Pajak Orang Pribadi Pada Kantor Pelayanan Pajak Pratama Palembang Seberang Ulu." Eprints.Mdp.Ac.Id.

Widyastuti, Ella. 2015. "Pengaruh Tingkat Pemahaman Wajib Pajak Dan Kualitas Pelayanan Fiskus Dan Lingkungan Wp Terhadap Tingkat Kepatuhan Wajib Pajak Pph Orang Pribadi (Studi Empiris Pada Kpp Pratama Surakarta)." Eprints.Ums.Ac.Id.

Winerungan, Oktaviane Lidya. 2013. Sosialisasi Perpajakan, Pelayanan Fiskus dan Sanksi PerpajakanTerhadap Kepatuhan WPOP di KPP Manado dan KPP Bitung. Jurnal EMBA 961 Vol.1 No.3 September 2013.70. 